\title{
Europeanising Migration in Multicultural Spain and Portugal During and After the Decolonisation Era
}

\author{
ELIZABETH BUETTNER* \\ E-mail: e.a.buettner@uva.nl
}

Post-1945 Spanish and Portuguese emigration and immigration histories encapsulate the Iberian region's long-standing interconnectedness with the wider world (particularly Latin America and Africa) and other parts of Europe alike. Portugal and Spain have both been part of multiple migration systems as important sending countries that ultimately experienced an international migration turnaround owing to their transition to democracy, decolonisation, and accession to a European Union in which internal freedom of movement counted among its core principles. With the aftermath of the 2008 financial crisis and Europe's migration crisis of the 2010s serving as its vantage point, this article considers these topics as they intersect with issues that include nationality and citizenship, race and racism, and religion and Islamophobia in multicultural Spain and Portugal.

Keywords: Spain, Portugal, decolonisation, migration, nationality, racism, Islamophobia, European integration

In 2018 and 2019, Iberian political and societal debates provided a clear demonstration of the potency that intercultural and colonial encounters of the past still retain in countries now markedly changed by migration. Spain witnessed Vox, a populist party established as recently as 2013, make its electoral breakthrough in regional elections in Andalusia late in 2018 before moving on to win twenty-four seats in the national parliament the following April—without doubt the biggest achievement of Spain's far right since the end of Francisco Franco's dictatorship in 1975. Its founder, Santiago Abascal, made headlines and secured votes with a platform steeped in nationalism, with its enemies encompassing not only Catalan separatists but particularly migrants. Significantly, it 
was not migrants per se who found themselves targeted for exclusion but Muslims first and foremost. At the same time that Vox demanded that a wall be built to seal Ceuta and Melilla, Spain's two enclaves on the southern Mediterranean coast, off from neighbouring Morocco to keep out new African migrants (most of whom were presumed to be Muslim), it stressed its strong preference for migrants from Latin American countries that had formed part of Spain's maritime empire for centuries. Abascal notoriously demanded that Spain's Roman Catholic culture, traditions, and borders be defended through a Reconquista - an explicit rhetorical return to Spain's expulsion of the Moors in 1492, the same year that Columbus's voyage launched Spain's overseas empire in and beyond the Americas. ${ }^{1}$ Keeping Muslims out while facilitating entry for Spanish-speaking Catholics from across the Atlantic had deep roots in Spain's history, both within the Iberian peninsula under eight centuries of Moorish domination and outside it through its own global empire.

Portugal, meanwhile, simultaneously experienced its own returns to its colonial past and encountered dilemmas extending from present-day multicultural diversity. Islamophobic populism in contemporary Portuguese public life has never approached that gaining an increasingly secure political footing in Spain, but Portugal in 2018 and 2019 witnessed fiery exchanges surrounding proposals to commemorate the nation's long history of involvement with transatlantic slavery in the form of a memorial in Lisbon together with another disputed initiative to open a new museum celebrating the overseas "Discoveries" of the fifteenth and sixteenth centuries - controversies that show no signs of dying down in the near future. Parallel to this were disturbances over the racism in public life that has adversely affected the lives of black Portuguese, many of whom struggle on Portugal's urban peripheries. Descended largely from immigrants from the Cape Verde Islands, Angola, Mozambique, and other former Portuguese colonies, ethnic minorities continue to suffer social, economic, and spatial marginalisation and many other forms of exclusion, not to mention police brutality. Stories dominating the media in 2019 included, among others, videos that went viral in January showing excessive use of force against black women in the Bairro da Jamaica outside Lisbon that galvanised large protest demonstrations, as well as the guilty verdict handed down in May for eight white officers for the unjustified arrest, physical assault, and kidnapping of six young black men from Cova da Moura - a disadvantaged neighbourhood mainly inhabited by Cape Verdean immigrants. Institutionalised police racism has also been blamed for at least ten deaths in Portugal in the past fifteen years alone. ${ }^{2}$

Such episodes testify to the shadows cast over both Iberian countries by centuries-old histories and the events of the past century alike - histories of maritime exploration, conquest, and colonisation; of migration (including forced migration through the slave trade); and of dictatorships that held sway in Spain under Franco between 1939 and 1975 and in Portugal, mainly under António de Oliveira Salazar, between 1926 and 1974. Racism in society and public institutions like the police; Islamophobia; colonial pasts often still presented in a largely positive light, together with the mounting challenges to all three: all count as familiar phenomena in many European countries after decolonisation overseas was accompanied or followed by increasing inward migration from erstwhile colonies 
and other places. As Andreas Stucki rightly stresses in his introduction to this dossier, Iberia is by no means a "case apart" in terms of its late colonial and decolonisation history. In this piece, I take up this point to evaluate how their histories of outward and inward migration further underscore how, national particularities aside, Spain and Portugal share important tendencies in common at the same time as they fit into wider European patterns. ${ }^{3}$ Their trajectories since the mid-twentieth century are indeed closely interconnected with Europe's postwar evolution - an evolution that itself was inseparable from late imperial histories overseas and the challenges to the colonial order that resulted in its collapse.

\section{Leaving Spain and Portugal in European, Late Imperial, and Transatlantic Contexts}

Postwar Iberian mobilities encapsulate the region's long-standing interconnectedness with the wider world and other parts of Europe alike, demonstrating both continuities and changes with earlier periods after 1945 as part of multiple migratory systems. ${ }^{4}$ Deep-seated poverty at home drove millions to emigrate to earn their livelihoods, with the main destination long being South America. Latin American countries decolonised early, with Brazil winning its independence from Portugal in 1822 and Spain losing most of its colonies in the 1820s but continuing to hold Cuba and Puerto Rico (alongside the Philippines in the Pacific) until 1898. Yet decolonisation did not disrupt transatlantic migration flows from Europe in the slightest. Brazil's Portuguese-born population continued to increase across the nineteenth and early twentieth centuries, while Argentina, Uruguay, Cuba, and other former Spanish colonies still proved to be the most common destination for Spanish emigrants. Although estimates differ, at least 2 million Portuguese emigrated between 1820 and 1930 while at least 3.5 million Spaniards settled in Latin American countries between 1846 and 1932. ${ }^{5}$ Emigration was long a structural feature of both Iberian societies, but in this they were far from alone on the European stage. Over 55 million people left Europe between 1815 and 1939, heading mainly to North and South America (ca. 35 million and 8 million respectively), while the rest embarked for other destinations, including those that remained European colonies. ${ }^{6}$

It was only after 1945 that Europe shifted from being a continent characterised overwhelmingly by emigration to being a common destination for new arrivals from overseas. As both Iberian examples underscore, the process was both gradual and highly uneven. Portugal and Spain counted among the countries that took considerably longer for the numbers entering to exceed those leaving on account of their political and economic predicaments. Not only were both states under authoritarian rule until the mid-1970s, but when compared to their northern neighbours they remained far poorer and economically underdeveloped. Political exiles who had fled once dictatorships came to power in the interwar years were joined by far greater numbers of labour migrants after 1945, and the tide only turned once the economic crises of the 1970 s alongside the return to democracy at home - and, in the case of Portugal, decolonisation in Africa-gradually resulted in new migration patterns. Until then, however, emigration remained a crucial 
safety valve and escape route, with the most important change being not from emigration to immigration but rather in where emigrants decided to go. While most Portuguese still opted for Brazil and most Spaniards for Spanish-speaking Latin American countries until the mid- to late 1950s, Western Europe subsequently overtook traditional transatlantic traffic as economic miracles at home coincided with what turned into the age of widescale decolonisation across much of Africa, Asia, and the Caribbean. ${ }^{7}$

At the very time when Britain, Belgium, France, and the Netherlands were forced to abandon much of their overseas empires, however, Portugal (and Spain to a lesser extent) insisted on staying put. While Spain's few remaining territories in North and West Africa never attracted numerous Spanish populations, Portugal's Estado Novo dictatorship tried hard to encourage its subjects to settle in the colonies that it redefined as "overseas provinces" of the Portuguese nation in 1951. Portuguese who relocated to Angola and Mozambique may have travelled thousands of kilometres from their birthplace, but technically they remained internal migrants within a Portugal that proudly insisted was a pluricontinental nation. Though Portuguese Africa's European settler populations indeed grew considerably in the succeeding years, official attempts to create "new Brazils" proved doomed to failure because most Portuguese voted with their feet and crossed the Pyrenees instead. As Victor Pereira has summarised, "Within a single year-1970 - departures to France were of the same order as those heading towards Angola and Mozambique between 1957 and 1974," a time when close to 1.4 million emigrated, approximately 900,000 of whom headed for France alone. By the time the Carnation Revolution of April 1974 finally spelled the end of the Estado Novo and simultaneously sealed the fate of Portuguese colonialism, "after less than twenty years of emigration, there were more Portuguese in France than in the overseas provinces after 450 years of colonisation." 8

Iberian migrants headed not only to France - the most popular destination for both Spanish and Portuguese by a considerable margin - but also to Switzerland, the Netherlands, West Germany, and other countries. Although the Federal Republic's postwar labour migrants are most commonly remembered as Turkish in Germany today, the one-millionth "guest worker" to enter in 1964 and be officially greeted with gifts of carnations and a motorcycle was Armando Rodrigues, who arrived on a train together with over a thousand other Portuguese countrymen together with Spaniards seeking employment. ${ }^{9}$ Mobility across European borders did not simply chronologically coincide with late colonialism and then widespread decolonisation, however: it interacted with it on multiple levels. Young Portuguese men evading years of obligatory military service in colonial wars in Portuguese Africa comprised part of the migration wave to France and other booming economies with jobs to offer that were unavailable at home. Upon arrival they formed part of a larger multiethnic population of migrants both from within and beyond Europe alike, a population in which colonial and ultimately postcolonial peoples alongside Turks featured prominently.

The French case illustrates how Iberian migrants by turns resembled and differed from newcomers from outside Europe, the most numerous being Algerians but also including other North and sub-Saharan Africans and French Antilleans. ${ }^{10}$ Like Arabs and Berbers 
from an Algeria which was French until winning its independence after a long decolonisation war in 1962, most disadvantaged Portuguese and Spanish who moved to cities like Paris in the 1950s and 1960s literally lived on the margins of society-often in the bidonvilles (shanty towns) located on the urban peripheries characterised by self-built ramshackle structures and a lack of access to basic facilities and running water. Writing about the terrible conditions suffered by residents of overcrowded and unhealthy bidonvilles in 1970, a French journalist deployed phrasing reminiscent of Frantz Fanon's to describe both Algerians and Portuguese alike as "les damnées de la région parisienne," or the "wretched of greater Paris." 11 Moreover, Portuguese and Spanish men commonly worked in the same employment sectors as Algerian men, doing strenuous and insecure jobs for low pay in the construction sector and in factories that native French workers preferred to avoid. Like Algerians, Portuguese and Spanish workers faced ethnic discrimination and stereotyping at work. As sociologist Juliette Minces observed in the early 1970s, if "every Algerian was Mohamed, every Portuguese was Antonio" in the eyes of their French coworkers. ${ }^{12}$ Many workers from North Africa and Iberia also faced substantial obstacles posed by high rates of illiteracy and being unable to speak French upon arrival.

Similarities with respect to their socioeconomic circumstances render the distinctions between Portuguese and Algerian migrants all the more significant in terms of what they reveal about their levels of acceptance within the receiving society. Algerians and others from France's empire (renamed the French Union in 1946) benefitted from French imperial citizenship after the late 1940s, meaning that their journeys into metropolitan France were undertaken legally as nationals with the right to free circulation-rights that were not immediately withdrawn upon decolonisation but which lasted until the late 1960s and early 1970s. ${ }^{13}$ Many Portuguese (and Spanish), by contrast, arrived illegally with the aid of smuggling networks that organised dangerous, clandestine journeys through fascist Spain and across the mountains. Many who crossed the border during the time of the "salto"- the "great leap" of mass postwar emigration abroad that peaked in the 1960s and early 1970s, when over one-tenth of Portugal's entire population left—carried only the proverbial "rabbit's passport" in lieu of official authorisation from a state that unsuccessfully tried to control the volume of departures. ${ }^{14}$

Citizenship and formal migration rights, however, did little to pave the way for French acceptance of Algerians, just as lacking both did not hinder that of Spanish and Portuguese in the longer term. North Africans remained widely disparaged as "immigrants" who allegedly would never integrate within French society - "Arabs" whose culture and religious background rendered them perpetually dangerous Muslims within a France that, while insistently secular in its public life, remained deeply embedded in Roman Catholic culture and assumptions. European foreigners, by contrast, were valued as likely to assimilate well into French society and seen as akin to "our brothers," particularly if they were "Catholic and Mediterranean like the Spaniards and Portuguese," as one newspaper article from 1984 put it. ${ }^{15}$ Within a France where anxieties about demographic decline had been a long-standing feature of political and social discourse, commentators who were deeply worried about the "problem" of large Muslim families did not extend their concerns to Iberian immigrants. Not only was their status regularised 
on account of the need for their labour; so too was the settlement of Iberian women and families encouraged as a valuable demographic asset. Spanish and Portuguese women, whether single or married-who respectively constituted approximately 44 and 30 percent of these expatriate communities in 1962 and 47 and 46 percent by 1975-were welcomed not only as domestic workers and concierges but as mothers of the next generation deemed likely to be fully assimilated and acceptably French. ${ }^{16}$

In sum, North Africans from south of the Mediterranean were consigned to the status of permanent outsiders in France regardless of their nationality and birthplace, while Iberian migrants from north of the Mediterranean were rendered largely unproblematic. France's Spanish presence peaked at around six hundred thousand in the late 1960s, while its Portuguese population, totalling over eight hundred thousand by the late 1970s, alternated with that from Algeria as France's largest- and second-largest migrant groups. ${ }^{17}$ Yet over time they grew increasingly invisible in public discourse regardless of their numbers. They owed what Albano Cordeiro has termed "this absence, which is called integration" to their favourable juxtaposition with North Africans. ${ }^{18}$ Whether explicitly stated or not, openly admitted beliefs about cultural, religious, and linguistic proximity to France's majority population came together with implicit ethnic and racial preferences. But which groups proved to be their equivalents once Spain and Portugal shifted to become societies where inward migration finally outweighed emigration?

\section{Inward Migration, Inclusion, and Exclusion in Postcolonial Portugal and Spain}

Although colonised peoples from Iberian empires had been present within imperial metropoles for centuries, their numbers in the modern period had long been small, paling into insignificance when compared to the high volume of Spanish and Portuguese departures. More students and workers gradually arrived after 1945, the most important being those from the Cape Verde Islands who entered mainland Portugal during and after the 1960s. Theirs was effectively a "substitution migration": with hundreds of thousands of Portuguese conscripted into the army to fight colonial wars in Africa or flocking to France and other European countries in search of better livelihoods, Portugal paradoxically faced an unaccustomed shortage of workers in construction, domestic service, and other low-paid sectors. In and around Lisbon, Cape Verdeans performed similar unskilled work that Portuguese themselves earned more money for doing abroad; moreover, they lived in slums on urban peripheries comparable to France's bidonvilles. ${ }^{19}$ Like Algerians and other late colonial migrants to France, moreover, Cape Verdeans arrived with the benefit of nationality. Just as those leaving European Portugal for the "overseas provinces" officially moved within the confines of a nation that the Estado Novo insisted was a pluricontental one, new legislation in 1959 turned those born on Portuguese territory overseas into Portuguese citizens, regardless of race. ${ }^{20}$

The "international migration turnaround" that ultimately occurred in Portugal and Spain, however, would only come during and after their transitions to democracy and 
decolonisation in the mid-1970s. ${ }^{21}$ Several hundred thousand Spanish and Portuguese political exiles and workers came home from other European countries soon after the fall of the Estado Novo and the death of Franco, while others returned once Portugal's African colonies achieved independence in 1975 and Spain finally pulled out of Western Sahara between 1975 and $1976 .^{22}$ Spain's influx of retornados (returnees) whether from Spanish Morocco (which became integrated into an independent Morocco between 1956 and 1969), from Equatorial Guinea (which became independent in 1968), and ultimately from Western Sahara-was miniscule when compared to Portugal's. Once its settler societies in Africa became unsustainable upon decolonisation, between five hundred thousand and eight hundred thousand retornados fled, largely heading to mainland Portugal; most who fell within this category were white, although a small minority were black, mestiço, or of other ethnic backgrounds. ${ }^{23}$

Decolonisation resulted in inward mobility that put one of Portugal's signature colonial ideologies to the test. Since the 1950s, lusotropicalism (first conceptualised in the 1930 s by the Brazilian sociologist Gilberto Freyre) had been enthusiastically taken up by the Salazar regime in its propaganda efforts aiming to legitimise Portugal's ongoing claims overseas in the face of mounting international and nationalist challenges. Its portrayal of Portuguese societies in Africa and Asia as uniquely benevolent and harmonious realms where racial mixing and cultural hybridity were accepted extended to insistent denials that racism and racial inequalities existed. ${ }^{24}$ Lusotropicalist rhetoric never accurately described the reality of life in the "overseas provinces" for most blacks and mestiços who suffered multiple forms of discrimination, but its assertive theoretical multiracialism did inform the inclusive late-colonial nationality policy noted above that transcended race and place of birth.

Once decolonisation transformed Portugal from a pluricontinental nation into a much smaller European one, however, new democratic governments quickly went about rolling back access to nationality. Legislation passed in 1975 and 1981 retreated from a principle of Portuguese citizenship based upon jus soli (place of birth) in favour of citizenship via jus sanguinis (by "blood," or descent from parents who were citizens). These moves placed severe limits on who could legally enter postcolonial Portugal from its defunct empire. Retornados from former settler colonies (both those who were white and those who had one Portuguese and one African parent) could freely return, but most Africans and Asians who once counted as Portuguese because they had been born in a Portuguese "overseas province" no longer qualified as such on account of ancestry. Decolonisation transformed them from fellow citizens into foreigners and turned those who relocated to Portugal into immigrants as opposed to internal migrants within a Portugal that had once spanned many continents. ${ }^{25}$ Explicitly racial criteria for citizenship may have been lacking, but in practice the new citizenship parameters spelled exclusion for most who were not white but born in former Portuguese colonies. By contrast, those of Portuguese ancestry born abroad - whether in Brazil, France, Germany, or other common emigrant destinations - resembled the retornados from Africa and continued to enjoy access to citizenship denied to other groups.

Postcolonial Portugal thus turned towards what Ana Paula Bela Horta has termed "a conception of the nation as an imagined community of descent that transcended territorial 
boundaries." Embracing "Portuguese of the Diaspora" living abroad went hand in hand with delegitimising ethnic minority diasporas within Portugal once the "overseas provinces" became history. ${ }^{26}$ Despite this, the pattern established mainly by Cape Verdeans in the 1960s was set to continue when Portugal shifted to becoming a net receiver of migrants. Once Portugal benefitted from economic growth after its accession to the European Economic Community in 1986, growing numbers of Portuguese-speaking Africans arrived and did unskilled jobs similar to those in which Cape Verdeans were already well represented. Although most lived and worked in Portugal illegally at the beginning, the state periodically regularised their status in light of their importance to the labour market in growing sectors like public works, construction, domestic service, and the hotel, catering, and tourism industries. Legal residence, however, often failed to translate into social inclusion and full acceptance for these communities. Just as racism was once pervasive yet officially denied in lusophone Africa under Portuguese colonialism despite celebratory lusotropicalist claims to the contrary, so too did racial biases, stereotyping, and discrimination remain prevalent in the postcolonial metropole - a Portugal still wont to deny racism's existence or extent in a manner revealing the durability of disabling lusotropical myths. ${ }^{27}$

Thanks to its colonial heritage, postcolonial recalibration of its citizenship laws, and approach to regularising illegal residents from lusophone countries, by the early twentyfirst century Portuguese-speakers - both those with and those without documented Portuguese ancestors - accounted for a considerable portion of Portugal's more than four hundred thousand foreign-origin inhabitants. In 2011, the largest group came from Brazil (25.5 percent), Cape Verdeans slightly exceeded 10 percent, and Angolans and other Lusophone groups were also a substantial presence. ${ }^{28}$ By this time, Spain too had undergone not simply an "international migration turnaround" of its own after entering the EEC in the same year as Portugal. Even more than was the case in Portugal, it experienced a phenomenal transformation from a historic sending society into a common destination offering attractive economic conditions and a stable democracy after Franco. Spain's foreign population rose from a mere two hundred thousand in 1981 to exceed six million by 2008 , with the late 1990 s to the early 2000 s seeing particularly striking levels of growth. ${ }^{29}$

Like Portugal, Spain attracted migrants both from colonies long lost, mainly in Latin America, and "overseas provinces" that survived until or after the 1950s, but the balance was even more heavily weighted towards the former than was the case with Portugal and its sizeable Brazilian-born community. While Equatorial Guineans fleeing poverty and a ruthless dictatorship at home numbered only about eleven thousand in 2000, Latin Americans formed the largest group by far, collectively comprising over 28 percent in 2012. ${ }^{30}$ This was attributable in part to the economic and political crises that caused many to seek their fortunes abroad as well as to the ongoing salience of hispanidad, Spain's version of Portuguese lusotropicalism, and its favourable treatment accorded to descendants of earlier emigrants in its nationality legislation.

Hispanidad owed its origins to what was long rued as Spain's national "disaster" when it rapidly met with defeat at the hands of the United States during the 
Spanish-American War of 1898 and lost what was left of its Caribbean and Pacific territories. Its coalescence and coming of age as an ideology only occurred under fascism in the 1930s and 1940s. From then on, the regime celebrated an allegedly harmonious colonial past that sowed the seeds of the nation's indestructible "spiritual" links with farflung Hispanic peoples through shared Roman Catholicism, their conjoined history, and a common language and culture that survived long after colonies became independent. In its denial of the ubiquity of cultural racism and much else, hispanidad bore considerable resemblance to Portugal's insistence on the indivisible nature of its pluricontinental nation, even if most of the places upon which Spain set its sights no longer fell under its jurisdiction. ${ }^{31}$ The continuity of hispanidad's links between places and peoples was described by its champions as "a Geography without borders" with "a single consciousness of the Hispanic World"; as for the relations between Spain and Hispanic America, "We are they [them], and they shall always be ourselves [us]," as Ramiro Ledesma Ramos proclaimed in $1931 .^{32}$

In addition to updating hispanidad by extending it to encompass Spain's “African vocation" in the 1950s - a time when Spain also followed in Portugal's footsteps by declaring its African colonies to be Spanish "provinces"-ideologues deployed familial rhetoric when describing Spain's maternal or fraternal sentiments towards the peoples of its former and current overseas possessions that crossed racial lines. ${ }^{33}$ Nationality policies dating back to the Civil Code of 1889 and reinforced with constitutional changes in 1954, however, told a different story: that of Spain's long-standing emphasis on descent above all as the primary determinant of citizenship, with birthplace consigned to a secondary role. This greatly facilitated access to dual nationality for the children and grandchildren of the many Spanish emigrants who had continued to settle in significant numbers in Argentina, Uruguay, and other Latin American countries until the mid-twentieth century, together with their counterparts who had set out for Western European destinations. Crucially, Spain's transition to democracy after Franco's death did not overturn this approach. Jus sanguinis still remained the basis of Spanish nationality, while later changes up until and including the reformed Civil Code of 2002 were explicitly intended to allow Spanish emigrants to retain, recover, and pass along their nationality to their descendants. ${ }^{34}$

Preferential access to Spanish nationality via Spanish ancestry counts as one of several ways that prospective migrants from many former colonies enjoy privileged status compared with other newcomers within postcolonial Spain. The "ethnic capital" bestowed by ancestry, after all, worked more in favour of some Latin Americans - namely those from Argentina and other once-common European emigrant destinations - than others from Ecuador, Colombia, Bolivia, and Peru, all of which had historically attracted far fewer departees and had far larger indigenous and mixed-heritage populations. ${ }^{35}$ Despite this, the latter countries have consistently ranked high among the top Latin American nationalities living in Spain by the early twenty-first century, with Ecuadorians, the largest group, totalling approximately 471,000 by $2012 .{ }^{36}$

Even without documented Spanish forebears, Latin Americans were widely seen as desirable immigrants for reasons that harkened back to hispanidad ideologies, namely 
Roman Catholicism together with a common language and presumed cultural affinities. These qualities rendered them good candidates for integration into Spanish society, yet did not protect them from xenophobia and discrimination. Migrants from Andean countries in particular-who tended on average to be poorer, less educated, and darker-skinned than Spain's Argentinean population-readily found themselves looked down upon as "sudacas," a highly derogatory term for South Americans, often those of Amerindian appearance whose physiognomies and accents caused them to stand out. $^{37}$ This corresponded to the precarious position of most Ecuadorians and other Latin Americans within the labour market. As Emma Martín Díaz, Francisco Cuberos Gallardo, and Simone Castellani have argued, workers from Latin America "are as desirable as they are exploitable." 38 The sectors in which Ecuadorians and other underprivileged Latin Americans commonly work (construction, public works, domestic service, the tourism industry, and hospitality and catering, with the addition of agriculture in the Spanish case) are precisely those that had traditionally employed countless Spaniards and Portuguese along with Algerians and other groups in more affluent European countries and that still employ many Cape Verdeans and other Lusophone Africans in Portugal. Women constitute a significant proportion of these migrant groups, doing lowpaid, unskilled jobs in hotels, care facilities, and private homes, and the "employment exploitation they suffer is not mitigated by their supposed cultural compatibility" in the least. $^{39}$

Latin American-origin workers in low-status occupations, however, were seen not simply in terms of their relative cultural proximity to other Spaniards and thus imagined as easily integrated. They were habitually compared with other sizeable migrant groups, first and foremost Moroccans - Spain's biggest non-European-origin community of all and forming 11 percent of its foreign-born population by 2012. Alongside playing crucial roles in Spain's low-paid workforce (particularly in Andalusia's burgeoning greenhouse agricultural sector), Moroccans occupy a cultural place in the imagination similar to that of Algerians, Turks, Pakistanis, Bangladeshis, and other groups in France and other Western European countries: that of the supposedly unassimilable "other" whose Islamic background is used to explain and justify fear and exclusion. ${ }^{40}$

Moroccans are Spain's most visible migrant community by far, regularly singled out by the media and conservative politicians up to and including today's Vox affiliates. Rendered as profoundly different from "us," Moroccans are not simply "non-citizens" but effectively "anti-citizens" who threaten "our values." Their alleged incompatibility has much to do with religious difference within a Spain which, like a number of other European countries, remains saturated with Catholic traditions despite its increasing secularity in many aspects of everyday life. ${ }^{41}$ Hostility towards Islam both belies Spain's own North African and Islamic heritage yet is intimately connected with it, with its eight centuries of Moorish occupation maintaining a central place in Spain's historical memory over five hundred years after the Reconquista. ${ }^{42}$ As Ricard Zapata-Barrero stresses, Spanish national identity "has been built in opposition to the picture of the Muslim in general and the Moroccan in particular, considered in pejorative terms as 'the Moor' ('el moro')." While today's Moroccan-origin community has largely arrived since the 
1990s, "Islam in Spain is not a new reality that citizens are discovering, but a historical fact that people tend to repress."43

This pre-modern history of Moorish occupation followed by expulsion is crucial to understanding why, despite parts of Morocco having been a Spanish protectorate, Moroccans are not among the nationalities receiving special consideration with respect to acquiring citizenship. They exist outside a national construct that accords preferential treatment to migrants from many other former Spanish territories, but which strongly favours those who possess ancestral and/or linguistic, cultural, and especially religious attributes seen as tied to Spain's. This is testament partly to hispanidad's survival long after fascism and imperialism and partly to the ways Islamophobia has become an ensconced transnational Western phenomenon. ${ }^{44}$ In the Spanish case, Islamist terrorist attacks in the United States on 11 September 2001 and Madrid on 11 March 2004 added greatly to existing perceptions of Muslims as dangerous outsiders who could never belong; today, conservative rhetoric emanating from politicians in the Partido Popular (or its erstwhile affiliates like Santiago Abascal, who broke away to form Vox) still keeps the "problems" attached to Moroccans and other Muslims continually in the spotlight.

\section{Conclusion: Iberian Migration and the European Union in Times of Crisis}

This "desire to forget the Islamic past, by a country that for centuries either ruled or was ruled by Muslims, and that still holds territories in North Africa," as Hishaam Aidi writes, thus remains a Spanish conundrum. ${ }^{45}$ Ceuta and Melilla, the small territories in question, are geographically surrounded by Morocco, which counters Spain's insistence that they are integral to its national territory by claiming them to be colonies under foreign occupation. Theirs is not only a story of Spain's incomplete decolonisation but also the European Union's by extension, ever since Spain became an EU member state. Indeed, the enclaves add another chapter to Spain's migration history as well as to the EU's. Vox's call for a wall to be built between Ceuta and Melilla and Morocco and thereby keep unwanted African migrants from illegally crossing into Spanish/EU territory does not constitute a new departure by any means; it merely seeks an even more formidable level of Spanish/EU border controls than the highly militarised security system that is already in place, one that features three rings of six-metre-high fences enveloping each city. These surviving outposts that now take the EU onto African soil are only part of what render Spain a main gateway to Europe. ${ }^{46}$ Its long Mediterranean coastline makes it one of Europe's main points of arrival for the countless people risking their lives on unsafe, overcrowded boats in their quest to reach "Fortress Europe," both well before the current "refugee crisis" began dominating international news in 2015 and continuing ever since.

Uproar surrounding refugees and economic migrants, most of whom are presumed to be Muslim, comes in the wake of other forms of increased cross-border mobility. Since the fall of the Soviet bloc at the end of the 1980s, millions of Central and Eastern 
Europeans have joined others on the move by heading towards Western European countries in search of a better life. Like so many migrants before them, many relocated on what they imagined - initially at least — would be a temporary basis, intending to work hard and accumulate savings in jobs that pay substantially more than jobs (or the lack of jobs) on offer at home. The EU's eastward expansion since the series of accessions in 2004 and 2007 significantly accelerated patterns that were already in place, enabling many more Poles, Romanians, Bulgarians, and other nationalities to take advantage of internal freedom of movement. They headed west as well as south, joining Portugal and Spain's existing populations from their former colonies and elsewhere beyond Europe together with growing numbers of Western European professionals and retirees, all of whom play their own part in rendering both Iberian countries increasingly diverse multicultural nations. ${ }^{47}$

Within conventional low-skilled sectors, Eastern Europeans have laboured alongside migrant groups from outside Europe since the 1990s. Though they faced discrimination and can readily find themselves singled out on account of ethnic and national differences, in general they have attracted markedly less adverse attention than Portugal's postcolonial black and mestiço population and Spain's Moroccans and other minorities. Indeed, they are often said to be favoured over a range of groups from outside Europe. Describing Cape Verdean women's attitudes in Portugal, Luís Batalha put it thus: "Before, they thought the Portuguese were racist because they left the worst jobs for black people; now they think the Portuguese are racist because they prefer white European women to black women."48

Migration to Europe from former colonies thus demands to be analysed not only in relationship to distinct host societies but simultaneously as a counterpoint to a much broader history of intra-European mobilities between the mid- to late twentieth century and the present day. As a right-wing Spanish politician argued in 2000 when proposing how to prevent the "the problem of integration" in addition to "a fragmentary, non-pluralist, interculturalism which produces tensions and radicalisation," it was crucial "to favor the arrival of those who are more easily integratable, owing to linguistic and cultural affinity. Without doubt Latin Americans, Romanians, and Slavs are preferable to Africans," especially Maghrebis. ${ }^{49}$ Romanians could be viewed as favourably as Latin Americans (or indeed even more so) despite linguistic differences and a lack of Spanish cultural heritage, for they were commonly claimed to be "good workers" (in other words, those with "a willingness to do jobs that the natives are not doing," as David Cook-Martin and Anahí Viladrich phrase it). ${ }^{50}$

Eastern Europeans now occupy a position in both Iberian countries that is comparable to that of the Spanish and Portuguese themselves when they settled in France and other countries several decades earlier, where they too were often viewed as far more acceptable than Algerians and other ethnic and religious minorities from overseas empires. In decolonising and postcolonial Europe, what Eastern and Southern European foreigners were imagined to be- " "good workers," culturally similar to the majority regardless of linguistic differences upon arrival, and (more implicitly) Christian and white-was as important as what they were not: Algerian or Moroccan and thus mainly Muslim in 
some cases, or black or mixed-race in others. Migration trends in recent years have caused Eastern Europeans from within and indeed beyond the EU to feature among the largest foreign-born groups in both countries (with Spain's top three in 2012 being Romanian, Moroccan, and Ecuadorian and Portugal's top five in 2011 being Brazilian, Ukrainian, Cape Verdean, Romanian, and Angolan), but their degree of social visibility is no match for their numbers. ${ }^{51}$

Decades after becoming societies where inward migration outweighed outward migration, however, neither Portugal nor Spain has ceased to count among the sending countries. Emigration or simply temporary residence abroad for work or personal reasons has never stopped being a familiar part of the life course for many Spaniards and Portuguese, who can partake of the benefits of the EU's open borders just as peoples from other EU member states now do as a matter of course. ${ }^{52}$ After 2008, moreover, ordinary opportunities for mobility acquired new urgency in extraordinary circumstances when Europe's severe financial and debt crisis hit Southern European countries especially hard. High unemployment (particularly among young people) alongside underemployment relative to their educational attainments, skills, and ambitions led increasing numbers of Spanish and Portuguese "back to the suitcase." Like their forebears, today's Iberians actively seek opportunities in other European countries with stronger economies and job markets, where they might find themselves doing similar jobs under exploitative conditions as Eastern Europeans. ${ }^{53}$ Some also continue to move much farther afield, including back to former colonies overseas. The noticeable Portuguese presence in Angola for the first time since the retorados' en masse departure upon decolonisation provides only one of many striking examples of the ongoing salience of the multiple migratory systems in which Spaniards and Portuguese continue to operate in ever-changing postcolonial times. ${ }^{54}$

\section{Bibliography}

\section{Published Primary Sources}

Aguilera-Carnerero, Carmen. "VOX and the Spanish Muslim Community: The New 'Reconquista' of Spain." Open Democracy 23 January 2019, https:/www.opendemocracy.net/en/can-europe-make-it/ vox-and-spanish-muslim-community-new-reconquista-of-spa/.

Baqué, Irene, Bruno Rinvolucri, and Laurence Topham. “'When Franco Was Alive, It Was Safer': Inside Spain's Far-Right Battleground" (video). Guardian (London), 30 May 2019, https://www. theguardian.com/world/video/2019/may/30/when-franco-was-alive-it-was-safer-inside-spains-farright-battleground-video.

Fohr, Anne, et al.. "Immigrés? Vous voulez dire Arabes!" Le Nouvel Observateur, 30 November 1984, reprinted in Immigration in Post-War France: A Documentary Anthology, edited by Alec G. Hargreaves, 53-4. London: Methuen, 1987.

Kantor, Véronique. "Les damnées de la région parisienne." Combat, 21 and 22 February 1970. Ledesma Ramos, Ramiro. "La ambición nacional. España, sangre de Imperio. Nuestra idea imperial." La Conquista del Estado: Semanario de lucha y de información política 12 (1931): 1.

Minces. Juliette. Les travailleurs étrangers en France: enquête. Paris: Éditions du Seuil, 1973.

Minder, Raphael. "Far-Right, Anti-Immigrant Vox Party Gains a Toehold in Spain." New York Times, 8 January 2019. 
Pérez Agudo, Eduardo. Los geógrafos españoles y la geografia de la Hispanidad. Barcelona: Universidad de Barcelona, 1948.

"Portugal Police Convicted of Attack on Black Youths," BBC News, 20 May 2019, https://www. bbc.co.uk/news/world-europe-48345089.

Sousa, Ana Naomi de. "Lisbon's Bad Week: Police Brutality Reveals Portugal's Urban Reality." Guardian (London), 31 January 2019.

Vries, Joost de. "Pas op! Laat je niet uitbuiten in Nederland." De Volkskrant (Amsterdam), 4 May 2019.

\section{Secondary Sources}

Aidi, Hishaam D. "The Interference of al-Andalus: Spain, Islam, and the West." Social Text 24:2 (2006): 67-88.

Aixelà Cabré, Yolanda. “Equatorial Guinean Women's Roles after Migration to Spain: Conflicts between Women's Androcentric Socialization in Equatorial Guinea and Their Experiences after Migration." Urban Anthropology and Studies of Cultural Systems and World Economic Development 42:1/2 (2013): 1-55.

Åkesson, Lisa. Postcolonial Portuguese Migration to Angola: Migrants or Masters? Basingstoke: Palgrave Macmillan, 2018.

Alexander, Isabella. "Waiting to Burn: Spanish-Maghribi Relations and the Making of a New Migrant Class." Journal of North African Studies 24:1 (2019): 152-74.

Almeida, Miguel Vale de. An Earth-Colored Sea: 'Race,' Culture, and the Politics of Identity in the Postcolonial Portuguese-Speaking World. New York: Berghahn, 2004.

Arocena, Felipe. "From Emigrant Spain to Immigrant Spain.” Race \& Class 53:1 (2011): 89-99.

Bachoud, Andrée, and Genevieve Dreyfus-Armand. "Des Espagnols aussi divers que nombreux, Paris 1945-1974." In Le Paris des étrangers depuis 1945, edited by Antoine Marès and Pierre Milza, 55-76. Paris: Éditions de la Sorbonne, 1995. Online version, http://books. openedition.org/psorbonne/961.

Baganha, Maria I. "The Lusophone Migratory System: Patterns and Trends." International Migration 47:3 (2009): 5-20.

—. "Portuguese Emigration after World War II." In Modern Portugal, edited by António Costa Pinto, 189-205. Palo Alto: Society for the Promotion of Science and Scholarship, 1998.

Baganha, Maria I., and Constança Urbano de Sousa. "Portugal." In Acquisition and Loss of Nationality: Policies and Trends in 15 European States, Vol. 2: Country Analyses, edited by Rainer Bauböck et al., 435-76. Amsterdam: Amsterdam University Press, 2006.

Batalha, Luís. The Cape Verdean Diaspora in Portugal: Colonial Subjects in a Postcolonial World. Lanham, Md.: Lexington Books, 2004.

Bender, Gerald J. Angola under the Portuguese: The Myth and the Reality. Trenton, N.J.: Free Africa World Press, 2004; originally published London, 1978.

Box, Zira. "Spanish Imperial Destiny: The Concept of Empire during Early Francoism," Contributions to the History of Concepts 8:1 (2013): 89-106.

Brettell, Caroline B. "The Emigrant, the Nation, and the State in Nineteenth- and Twentieth-Century Portugal: An Anthropological Approach.” Portuguese Studies Review 2:2 (1993): 51-65.

Buettner, Elizabeth. Europe after Empire: Decolonization, Society, and Culture. Cambridge: Cambridge University Press, 2016.

Carling, Jørgen, and Lisa Åkesson. "Mobility at the Heart of a Nation: Patterns and Meanings of Cape Verdean Migration." International Migration 47:3 (2009): 123-55.

Carr, Matthew. "Policing the Frontier: Ceuta and Melilla." Race and Class 39:1 (1997): 61-6.

Castelo, Cláudia. "O modo português de estar no mundo": O luso-tropicalismo e a ideologia colonial portuguesa (1933-1961). Porto: Afrontamento, 1998. 
Chin, Rita. The Guest Worker Question in Postwar Germany. Cambridge: Cambridge University Press, 2007.

Cook-Martin, David, and Anahí Viladrich. "The Problem with Similarity: Ethnic-Affinity Migrants in Spain." Journal of Ethnic and Migration Studies 35:1 (2009): 151-70.

Cooper, Frederick. Citizenship between Empire and Nation: Remaking France and French Africa, 1945-1960. Princeton, N.J.: Princeton University Press, 2014.

Cordeiro, Albano."Le paradoxe de l'immigration portugaise." Hommes et Migrations 1123 (1989): $25-32$.

_. "Les Portugais, une population 'invisible'?" In Immigration et intégration: l'état des savoirs, edited by Philippe Dewitte, 106-11. Paris: Éditions La Découverte, 1999.

Corkill, David, and Martin Eaton. "Multicultural Insertions in a Small Economy: Portugal's Immigrant Communities." South European Society and Politics 3:3 (1998): 149-68.

Domínguez Mujica, Josefina, Ramón Díaz-Hernández, and Juan Parreño Castellano. "Migrating Abroad to Get Ahead: The Emigration of Young Spanish Adults during the Financial Crisis." In Global Change and Human Mobility, edited by Josefina Domínguez Mujica, 202-23. Singapore: Springer, 2016.

Eaton, Martin. "Foreign Residents and Illegal Immigrants in Portugal." International Journal of Intercultural Research 22:1 (1998): 49-66.

"Espagnols et Portugais en France au XXe siècle. Travail et politiques migratoires," special issue, Exils et migrations ibériques au XXe siècle 2 (2006).

Fernández Vincente, María José. "Españoles fuera de España. Historia y memoria de la última ola migratoria española (1945-1980)." Amnis: Revue d'études des sociétés et cultures contemporaines Europe-Amérique 7 (2007). Online version, http://journals.openedition.org/amnis/799.

Fikes, Kesha. Managing African Portugal: The Citizen-Migrant Distinction. Durham: Duke University Press, 2009.

Flesler, Daniela. The Return of the Moor: Spanish Responses to Contemporary Moroccan Immigration. West Lafayette, Ind.: Purdue University Press, 2008.

Gabaccia, Donna R., Dirk Hoerder, and Adam Walaszek. "Emigration and Nation Building during the Mass Migrations from Europe." In Citizenship and Those Who Leave: The Politics of Emigration and Expatriation, edited by Nancy L. Green and François Weil, 63-90. Urbana: University of Illinois Press, 2007.

Geiger, Martin. "Towards an Inclusive Society? A Study on Local Actors and the Social Inclusion of Moroccan Agricultural Workers in the Province of Almería (Spain)." Migration: A European Journal of International Migration and Ethnic Relations 46-47 (2007): 33-53.

Glorius, Birgit. "New 'Guest Workers' from Spain? Exploring Migration to Germany in the Context of Economic and Societal Change." In Global Change and Human Mobility, edited by Josefina Domínguez Mujica, 225-47. Singapore: Springer, 2016.

Góis, Pedro, and José Carlos Marques. "Portugal as a Semi-Peripheral Country in the Global Migration System." International Migration 47:3 (2009): 21-50.

González-Enríque, Carmen. "Spain.” In European Immigration: A Sourcebook, 2nd ed., edited by Anna Triandafyllidou and Ruby Gropas, 339-50. Farnham: Ashgate, 2014.

González-Ferrer, Amparo, and Francisco Javier Moreno-Fuentes. "Back to the Suitcase? Emigration during the Great Recession in Spain." South European Society and Politics 22:4 (2017): 447-71.

Horta, Ana Paula Beja. Contested Citizenship: Immigration Politics and Grassroots Migrants' Organizations in Post-Colonial Portugal. New York: Center for Migration Studies, 2004.

Howe, Marvine. Al-Andalus Rediscovered: Iberia's New Muslims. London: Hurst, 2012.

Joppke, Christian. Selecting by Origin: Ethnic Migration in the Liberal State. Cambridge, Mass.: Harvard University Press, 2005. 
Kalter, Christoph. "Postcolonial People: 'Retornados,' Migration, and Decolonization in Portugal." Habilitationsschrift, Freie Universität Berlin, 2019.

King, Russell, Anthony Fielding, and Richard Black. "The International Migration Turnaround in Southern Europe." In Southern Europe and the New Immigrations, edited by Russell King and Richard Black, 1-25. Brighton: Sussex Academic Press, 1997.

Lillo, Natacha. La "petite Espagne" de la Plaine-Saint-Denis: 1900-1980. Paris: Les Éditions Autrement, 2004.

Lubkemann, Stephen C. "The Moral Economy of Portuguese Postcolonial Return." Diaspora 11:2 (2002): 189-213.

Martín Díaz, Emma, Francisco Cuberos Gallardo, and Simone Castellani. "Latin American Immigration to Spain: Discourses and Practices from 'La Madre Patria." Cultural Studies 26:6 (2012): 814-41.

Mateos, Pablo, and Jorge Durand. "Residence vs. Ancestry in Acquisition of Spanish Citizenship: A Netnography Approach." Migraciones Internacionales 6:4 (2012): 9-46.

Medina-Doménech, Rosa. "Scientific Technologies of National Identity as Colonial Legacies: Extracting the Spanish Nation from Equatorial Guinea." Social Studies of Science 39:1 (2009): 81-112.

Moreno Fuentes, Francisco Javier. "Migration and Spanish Nationality Law." In Towards a European Nationality: Citizenship, Immigration and Nationality Law in the EU, edited by Randall Hansen and Patrick Weil, 118-42. Basingstoke: Palgrave, 2001.

Morier-Genoud, Eric, and Michel Cahen, eds. Imperial Migrations: Colonial Communities and Diaspora in the Portuguese World. Basingstoke: Palgrave Macmillan, 2013.

Newitt, Malyn. Emigration and the Sea: An Alternative History of Portugal and the Portuguese. Oxford: Oxford University Press, 2015.

Oso Casas, Laura. Españolas en París. Estrategias de ahorro y consumo en las migraciones internacionales. Barcelona: Edicions Bellaterra, 2004.

Peixoto, João. "Portugal." In European Immigration: A Sourcebook, 2nd ed., edited by Anna Triandafyllidou and Ruby Gropas, 287-99. Farnham: Ashgate, 2014.

Pereira, Victor. La dictature de Salazar face à l'émigration: l'État portugais et ses migrants en France (1957-1974). Paris: Presses de Sciences Po, 2012.

- "Portuguese Migrants and Portugal: Elite Discourse and Transnational Practices." In $A$ Century of Transnationalism: Immigrants and Their Homeland Connections, edited by Nancy L. Green and Roger David Waldinger, 56-83. Urbana: University of Illinois Press, 2016.

Ponty, Janine. L'immigration dans les textes: France, 1789-2002. Paris: Éditions Belin, 2003.

Ramos, Rui Manuel Moura. "Migratory Movements and Nationality Law in Portugal." In Towards a European Nationality: Citizenship, Immigration and Nationality Law in the EU, edited by Randall Hansen and Patrick Weil, 214-29. Basingstoke: Palgrave, 2001.

Recchi, Ettore, and Anna Triandafyllidou. "Crossing Over, Heading West and South: Mobility, Citizenship, and Employment in the Enlarged Europe." In Labour Migration in Europe, edited by Georg Menz and Alexander Caviedes, 127-49. Basingstoke: Palgrave Macmillan, 2010.

Reiter, Bernd. "The Perils of Empire: Nationhood and Citizenship in Portugal." Citizenship Studies 12:4 (2008): 397-412.

Ribert, Evelyne, and Bruno Tur. "The Role of Spanish Refugees in the Construction of the Migration Memory in France and Spain.” Journal of Intercultural Studies 34:6 (2013): 714-28.

Rogozen-Soltar, Mikaela H. Spain Unmoored: Migration, Conversion, and the Politics of Islam. Bloomington: Indiana University Press, 2017.

Rubio Marín, Ruth. "Spain." In Acquisition and Loss of Nationality: Policies and Trends in 15 European States, Vol. 2: Country Analyses, edited by Rainer Bauböck et al., 477-515. Amsterdam: Amsterdam University Press, 2006. 
Stucki, Andreas. "The Hard Side of Soft Power: Spanish Rhetorics of Empire from the 1950s to the 1970s." In Rhetorics of Empire: Languages of Colonial Conflict after 1900, edited by Martin Thomas and Richard Toye, 142-60. Manchester: Manchester University Press, 2017.

—. Violence and Gender in Africa's Iberian Colonies: Feminizing the Portuguese and Spanish Empire, 1950s-1970s. Cham, Switzerland: Palgrave Macmillan, 2019.

Ugarte, Michael. Africans in Europe: The Culture of Exile and Emigration from Equatorial Guinea to Spain. Urbana: University of Illinois Press, 2010.

Vala, Jorge, Diniz Lopes, and Marcus Lima. "Black Immigrants in Portugal: Luso-Tropicalism and Prejudice." Journal of Social Issues 64:2 (2008): 287-302.

Venturini, Alessandra. Postwar Migration in Southern Europe, 1950-2000: An Economic Analysis. Cambridge: Cambridge University Press, 2004.

Vivez-Gonzalez, Luna. "Insiders or Outsiders? Argentinean Immigrants in Spain." Citizenship Studies 15:2 (2011): 227-45.

Volovitch-Tavares, Christine. "Les Portugais dans la région parisienne depuis la fin de la Deuxième Guerre mondiale jusqu'en 1974." In Le Paris des étrangers depuis 1945, edited by Antoine Marès and Pierre Milza, 95-120. Paris: Éditions de la Sorbonne, 1995. Online version, http://books.openedition.org/psorbonne/965.

Volovitch-Tavares, Christine. Portugais à Champigny, le temps des baraques. Paris: Les Éditions Autrement, 1995.

Zahra, Tara. The Great Departure: Mass Migration from Eastern Europe and the Making of the Free World. New York: W. W. Norton, 2016.

Zapata-Barrero, Ricard. "Dynamics of Diversity: Old Questions, New Challenges." In The Multiculturalism Backlash: European Discourses, Policies and Practices, edited by Steven Vertovec and Susanne Wessendorf, 170-89. London: Routledge, 2010.

Zapata-Barrero, Ricard. "The Muslim Community and Spanish Tradition: Maurophobia as a Fact, and Impartiality as a Desideratum." In Multiculturalism, Muslims and Citizenship: A European Approach, edited by Tariq Modood, Anna Triandafyllidou, and Ricard Zapata-Barrero, 143-61. London: Routledge, 2006.

Zeneidi-Henry, Djemila. Gender, Temporary Work, and Migration Management: Global Food and Utilitarian Migration in Huelva, Spain. Cham: Palgrave Macmillan, 2017.

\section{Notes}

* Elizabeth Buettner is professor of modern history at the University of Amsterdam. Since her book Europe after Empire: Decolonization, Society, and Culture was published by Cambridge University Press in 2016, her research has extended further into the overlapping histories of postcolonial Europe, migration, and European integration. This work forms part of the ECHOES project which has received funding from the European Union's Horizon 2020 research and innovation programme under grant agreement No. 770248.

1 Minder, "Far-Right, Anti-Immigrant Vox"; Aguilera-Carnerero, "VOX and the Spanish Muslim Community”; Baqué et al., "“When Franco Was Alive."
2 Sousa, "Lisbon's Bad Week"; "Portugal Police Convicted of Attack on Black Youths."

3 Some of the topics below, particularly concerning Portugal, are explored comparatively together with Britain, France, Belgium, and the Netherlands in Buettner, Europe after Empire.

4 Baganha, "The Lusophone Migratory System," 5-20; Góis and Marques, "Portugal as a Semi-Peripheral Country," 21-50.

5 Pereira, "Portuguese Migrants and Portugal," 59, 65; Martín Díaz et al., "Latin American Immigration to Spain," 816. See also many of the essays in Morier-Genoud and Cahen, Imperial Migrations. 
6 Gabaccia et al., "Emigration and Nation Building," 63.

7 Newitt, Emigration and the Sea, 136, 15168; Venturini, Postwar Migration in Southern Europe, 8-17; Baganha, "Portuguese Emigration after World War II," 191-2; Brettell, "The Emigrant, the Nation, and the State," 54-6; Arocena, "From Emigrant Spain to Immigrant Spain," 91; Fernández Vincente, "Españoles fuera de España"; Ribert and Tur, "The Role of Spanish Refugees."

8 Pereira, "Portuguese Migrants and Portugal," 67; see also 59.

9 Chin, The Guest Worker Question, 1-2.

10 "Espagnols et Portugais en France au XXe siècle"; Oso Casas, Españolas en París; Lillo, La "petite Espagne"; Bachoud and Dreyfus-Armand, "Des Espagnols aussi divers que nombreux"; Volovitch-Tavares, "Les Portugais dans la région parisienne."

11 Kantor, "Les damnées de la région parisienne," discussed in Volovitch-Tavares, Portugais à Champigny, 49.

12 Minces, Les travailleurs étrangers, 204.

13 Cooper, Citizenship between Empire and Nation, 442, 445, and chaps. 2-3; Buettner, Europe after Empire, 285-7, 296-7.

14 Pereira, La dictature de Salazar.

15 Fohr et al., "Immigrés?," 53.

16 Ponty, L'immigration dans les textes, 311; Cordeiro, "Les Portugais," 106-11.

17 Ponty, L'immigration dans les textes, 310, 314, 328.

18 Cordeiro, "Le paradoxe," 25-6.

19 Batalha, The Cape Verdean Diaspora in Portugal; Fikes, Managing African Portugal; Corkill and Eaton, "Multicultural Insertions in a Small Economy," 151-2, 156. As Jørgen Carling and Lisa Åkesson point out, Cape Verdean migration has also extended to many other destinations within and beyond Europe. See "Mobility at the Heart of a Nation," especially 130-2 on the 1960 s to the 1980 s.

20 Baganha and de Sousa, "Portugal," 441; Ramos, "Migratory Movements," 214-17; Buettner, Europe after Empire, 200.

21 King et al., "The International Migration Turnaround," 1-25.
22 Moreno Fuentes, "Migration and Spanish Nationality Law," 130.

23 Lubkemann's work, including "The Moral Economy," offers an excellent summary; see also Buettner, Europe after Empire, 242-7, and especially Kalter, "Postcolonial People," which provides the most in-depth treatment to date.

24 On lusotropicalism, see Castelo, "O modo português de estar no mundo," 87-107; Bender, Angola under the Portuguese, chap. 1; Almeida, An Earth-Colored Sea, 46-61; Stucki, Violence and Gender in Africa's Iberian Colonies, 9, 129-34.

25 Ramos, "Migratory Movements," 217-27; Baganha and de Sousa, "Portugal," 44450, 460, 468-72; Reiter, "Perils of Empire," 408. Portuguese nationality based on jus sanguinis was retained until a partial shift back towards jus soli occurred in 2006.

26 Horta, Contested Citizenship, 51. See also 21, 55, 268-9; Joppke, Selecting by Origin, 132-5; Brettell, "The Emigrant, the Nation, and the State," 51-65; Buettner, Europe after Empire, 397-412. This derives directly from late colonial propaganda, whereby the integration of Portuguese spread across the globe was intended to enhance the pluricontinental myth that "Portugal was a not a small country." I am gratetful to Andreas Stucki for his insights on this point.

27 Eaton, "Foreign Residents and Illegal Immigrants," 49-66; Reiter, "Perils of Empire"; Vala et al., "Black Immigrants in Portugal," 287-302.

28 Peixoto, "Portugal," 292-6.

29 Arocena, "From Emigrant Spain to Immigrant Spain," 89-90.

30 González-Enríque, "Spain,” 339, 345; Aixelà Cabré, "Equatorial Guinean Women's Roles after Migration to Spain," 12-13. Further analysis of this group can be found in Ugarte, Africans in Europe.

31 Box, "Spanish Imperial Destiny"; Stucki, "The Hard Side of Soft Power," 143-4, 146, 155.

32 Medina-Doménech, "Scientific Technologies of National Identity." The 
quotes, which appear on p. 102 and p. 101, are respectively taken from Pérez Agudo, Los geógrafos españoles, 114, and Ledesma Ramos, "La ambición nacional," 1.

33 Stucki, Violence and Gender, 130-1; Stucki, "The Hard Side of Soft Power," 144; Medina-Doménech, "Scientific Technologies of National Identity," 103; Aidi, "The Interference of al-Andalus," 73.

34 Moreno Fuentes, "Migration and Spanish Nationality Law"; Cook-Martin and Viladrich, "The Problem with Similarity," 157; Vivez-Gonzalez, "Insiders or Outsiders?," 223-4; Rubio Marín, "Spain," 489-90; Joppke, Selecting by Origin, 114-21.

35 Mateos and Durand, "Residence vs. Ancestry," 9-46.

36 González-Enríque, "Spain," 345; see also Martín Díaz et al., "Latin American Immigration," 823, and Arocena, "From Emigrant Spain to Immigrant Spain," 93, for alternative figures.

37 Arocena, "From Emigrant Spain to Immigrant Spain," 90, 94; Vivez-Gonzalez, "Insiders or Outsiders?," 230, 233.

38 Martín Díaz et al., "Latin American Immigration," 830.

39 Ibid.

40 González-Enríque, "Spain,” 339, 345. On Moroccan agricultural workers, see Zeneidi-Henry, Gender, Temporary Work, and Migration Management; Geiger, "Towards an Inclusive Society?"

41 Zapata-Barrero, "Muslim Community," $152-5$.
42 Rogozen-Soltar, Spain Unmoored.

43 Zapata-Barrero, "Muslim Community," 143-4. See also Flesler, The Return of the Moor; Howe, Al-Aldalus Rediscovered.

44 Joppke, Selecting by Origin, 123-6, 156.

45 Aidi, "The Interference of al-Andalus," 85.

46 Alexander, "Waiting to Burn." See also Matthew Carr's description of the system already in place in the late 1990s in Carr, "Policing the Frontier."

47 For overviews, see Zahra, Great Departure, 272-301; Recchi and Triandafyllidou. "Crossing Over, Heading West and South."

48 Batalha, Cape Verdean Diaspora, 206.

49 Miguel Herrero de Miñón, quoted in El País, 8 October 2000, cited in Martín Díaz et al., "Latin American Immigration to Spain," 826.

50 Cook-Martin and Viladrich, "The Problem with Similarity," 159-62 (with quote taken from 161).

51 González-Enríque, "Spain,” 345; Peixoto, "Portugal," 292.

52 Baganha, "Lusophone Migratory System"; Góis and Marques, "Portugal as a Semi-Peripheral Country."

53 De Vries, "Pas op! Laat je niet uitbuiten in Nederland."

54 González-Ferrer and Moreno-Fuentes, "Back to the Suitcase?"; Pereira, "Portuguese Migrants," 60; Glorius, "New 'Guest Workers' from Spain?”; Domínguez Mujica et al., "Migrating Abroad to Get Ahead"; Åkesson, Postcolonial Portuguese Migration. 